\title{
Ozone correlations between mid-tropospheric partial columns and the near-surface at two mid-atlantic sites during the DISCOVER-AQ campaign in July 2011
}

\author{
Douglas K. Martins • Ryan M. Stauffer • Anne M. Thompson • \\ Hannah S. Halliday • Debra Kollonige • Everette Joseph • \\ Andrew J. Weinheimer
}

Received: 12 November 2012 / Accepted: 25 April 2013/

Published online: 12 May 2013

(C) The Author(s) 2013. This article is published with open access at Springerlink.com

\begin{abstract}
The current network of ground-based monitors for ozone $\left(\mathrm{O}_{3}\right)$ is limited due to the spatial heterogeneity of $\mathrm{O}_{3}$ at the surface. Satellite measurements can provide a solution to this limitation, but the lack of sensitivity of satellites to $\mathrm{O}_{3}$ within the boundary layer causes large uncertainties in satellite retrievals at the near-surface. The vertical variability of $\mathrm{O}_{3}$ was investigated using ozonesondes collected as part of NASA's Deriving Information on Surface Conditions from COlumn and VERtically Resolved Observations Relevant to Air Quality (DISCOVER-AQ) campaign during July 2011 in the Baltimore, MD/Washington D.C. metropolitan area. A subset of the ozonesonde measurements was corrected for a known bias from the electrochemical solution strength using new procedures based on laboratory and field tests. A significant correlation of $\mathrm{O}_{3}$ over the two sites with ozonesonde measurements (Edgewood and Beltsville, MD) was observed between the mid-troposphere $(7-10 \mathrm{~km})$ and the near-surface $(1-3 \mathrm{~km})$. A linear regression model based on the partial column amounts of $\mathrm{O}_{3}$ within these subregions was developed to calculate the near-surface $\mathrm{O}_{3}$ using mid-tropospheric satellite measurements from the Tropospheric Emission Spectrometer (TES) onboard the Aura spacecraft. The uncertainties of the calculated nearsurface $\mathrm{O}_{3}$ using TES mid-tropospheric satellite retrievals and a linear regression model were less than $20 \%$, which is less than that of the observed variability of $\mathrm{O}_{3}$ at the surface in this region. These results utilize a region of the troposphere to which existing satellites are more sensitive compared to the boundary layer and can provide information of $\mathrm{O}_{3}$ at the near-surface using existing satellite infrastructure and algorithms.
\end{abstract}

D. K. Martins $(\bowtie) \cdot$ R. M. Stauffer $\cdot$ A. M. Thompson $\cdot$ H. S. Halliday $・$ D. Kollonige Department of Meteorology, Pennsylvania State University, 503 Walker Building, University Park, PA 16802, USA

e-mail: dkm18@psu.edu

E. Joseph

Department of Physics and Astronomy, Howard University, 2355 6th St. NW, Washington, DC 20059, USA

A. J. Weinheimer

National Center for Atmospheric Research, PO Box 3000, Boulder, CO 80307-3000, USA 
Keywords Ozone $\cdot$ Ozonesondes $\cdot$ DISCOVER-AQ $\cdot$ TES $\cdot$ Satellite

\section{Introduction}

Retrieval of tropospheric ozone $\left(\mathrm{O}_{3}\right)$ concentrations from satellites can be challenging given optical interferences such as clouds, aerosols and the stratospheric $\mathrm{O}_{3}$ layer. State-of-the-art spectrometers and interferometers on board current satellites ranging from the microwave to the ultraviolet bands of the electromagnetic spectrum are used to retrieve total column $\mathrm{O}_{3}$ (TCO) and vertically-resolved $\mathrm{O}_{3}$ mixing ratios (Beer et al. 2001; Goldberg et al. 2003; Levelt et al. 2006; Waters et al. 2006; Clerbaux et al. 2009; Liu et al. 2010). The signal collected by satellites from the lower-free troposphere and the boundary layer is small, resulting in coarse vertical resolution $(\sim 5 \mathrm{~km})$ at these lower layers and increased uncertainty of the retrieved values (Bowman et al. 2002, 2006; Worden et al. 2004). Much work has been conducted to extract the tropospheric column $\mathrm{O}_{3}$ (TPCO) from the raw irradiances and/or TCO measurements (Fishman and Larsen 1987; Ziemke et al. 1998; 2006; Liu et al. 2006; Schoeberl et al. 2007). The validation of both TPCO and TCO amounts against independent datasets and/or model simulations have been extensive (Balis et al. 2007; Worden et al. 2007a; Kroon et al. 2008; Nassar et al. 2008; Osterman et al. 2008; Richards et al. 2008; Antón et al. 2009; Liu et al. 2010; Kroon et al. 2011). TES retrievals of vertically resolved $\mathrm{O}_{3}$ are generally biased high between 0 and $20 \%$ in the troposphere when compared to ozonesonde measurements (Nassar et al. 2008; Osterman et al. 2008; Boxe et al. 2010), and Ozone Monitoring Instrument (OMI; also on board Aura) ozone profile retrievals are biased high between 20 and $60 \%$ in the troposphere compared to ozonesonde measurements (Kroon et al. 2011). By combining satellite measurements of different spectral ranges (infrared and ultraviolet), improvements by a factor of two in the sensitivity to the lower tropospheric and boundary layer $\mathrm{O}_{3}$ have been observed and simulated (Worden et al. 2007b; Landgraf and Hasekamp 2007; Sellitto et al. 2011; Natraj et al. 2011; Zoogman et al. 2011). The inability of the current sun-synchronous, low-earth orbit satellite measurements to resolve $\mathrm{O}_{3}$ concentrations within the boundary layer has limited the application of satellite $\mathrm{O}_{3}$ observations for control and regulation purposes, the study of chemical and physical processes leading to the formation and transport of $\mathrm{O}_{3}$, and investigations of regional impacts of $\mathrm{O}_{3}$ to the health of humans and the biosphere.

Instrumentation, retrieval algorithms and data processing have become increasingly sophisticated, resulting in detection of plumes within the troposphere (Kar et al. 2010; Jourdain et al. 2007) and observations of impacts of $\mathrm{O}_{3}$ on the biosphere (Fishman et al. 2010). The previous studies have relied on either enhanced signals within plumes and/or temporal averaging to detect $\mathrm{O}_{3}$ mixing ratios within the troposphere, limiting the applications to higher frequency (i.e. diurnal) processes within the boundary layer.

Work has been conducted to quantify the correlation between $\mathrm{O}_{3}$ mixing ratios at the surface and partial column $\mathrm{O}_{3}$ amounts in the boundary layer $(0-3 \mathrm{~km})$ using ozonesonde datasets across North America (Chatfield and Esswein 2012). Correlation coefficients between 0.7 and 0.95 were observed. The applicability of these correlations to satellite retrievals assumes that satellite retrievals are sensitive to boundary layer atmospheric pollutants. The calculated averaging kernels used in the satellite retrievals within the boundary layer suggest that satellites are not sensitive to boundary layer pollutants (e.g. Bowman et al. 2006). Similar investigations within a more defined region over a shorter timescale can potentially reveal more information on the extent and processes behind vertical $\mathrm{O}_{3}$ correlations. 
At present, we have only polar-orbiting ozone satellites with limited lower tropospheric detection. Thus, techniques that can extract near-surface information from partial columns within the mid-to-upper troposphere are highly desirable. In this work, we present a promising technique to expand TES capabilities using campaign data from a prototypical pollution regime. We present an investigation of $\mathrm{O}_{3}$ variability and vertical correlations of $\mathrm{O}_{3}$ mixing ratios and partial columns at two sites in the mid-Atlantic United States. Detailed comparisons of ozonesondes with in situ aircraft and satellite measurements are provided. The results from this study are then used to derive near-surface $\mathrm{O}_{3}$ amounts using existing satellite measurements from the Tropospheric Emission Spectrometer (TES). This work utilizes the extensive set of observations collected as part of NASA's Deriving Information on Surface Conditions from COlumn and VERtically Resolved Observations Relevant to Air Quality (DISCOVER-AQ) campaign during July 2011 in the Baltimore, MD/Washington D.C. metropolitan area (Fig. 1). The campaign consisted of measurements from three aircraft, twelve ground stations, two free-flying and tether balloon systems, and a ship in the Chesapeake Bay (data publicly available at http://www-air.larc.nasa.gov/cgi-bin/ arcstat-d). A subset of these measurements (described below), specifically over Edgewood, MD (EW; Lat: 39.4100, Lon: -76.2967) approximately $30 \mathrm{~km}$ northeast of Baltimore, MD and Beltsville, MD (BV; Lat: 39.0540, Lon: -76.8773) approximately $22 \mathrm{~km}$ northeast of Washington, D.C. provide a description of the composition and dynamics of the atmosphere. The respective proximities of these sites to the Chesapeake Bay $(\sim 3 \mathrm{~km}$ for EW and $38 \mathrm{~km}$ for BV) allow the investigation of marine layers on upper tropospheric and near-surface $\mathrm{O}_{3}$ correlations. The objective of this study is to use correlation statistics to improve methods of obtaining near-surface $\mathrm{O}_{3}$ from satellite retrievals. The approaches taken within this manuscript apply to an operational satellite, but with further refinements with more campaign statistics, can also enhance retrievals from planned geostationary satellites (NASA's

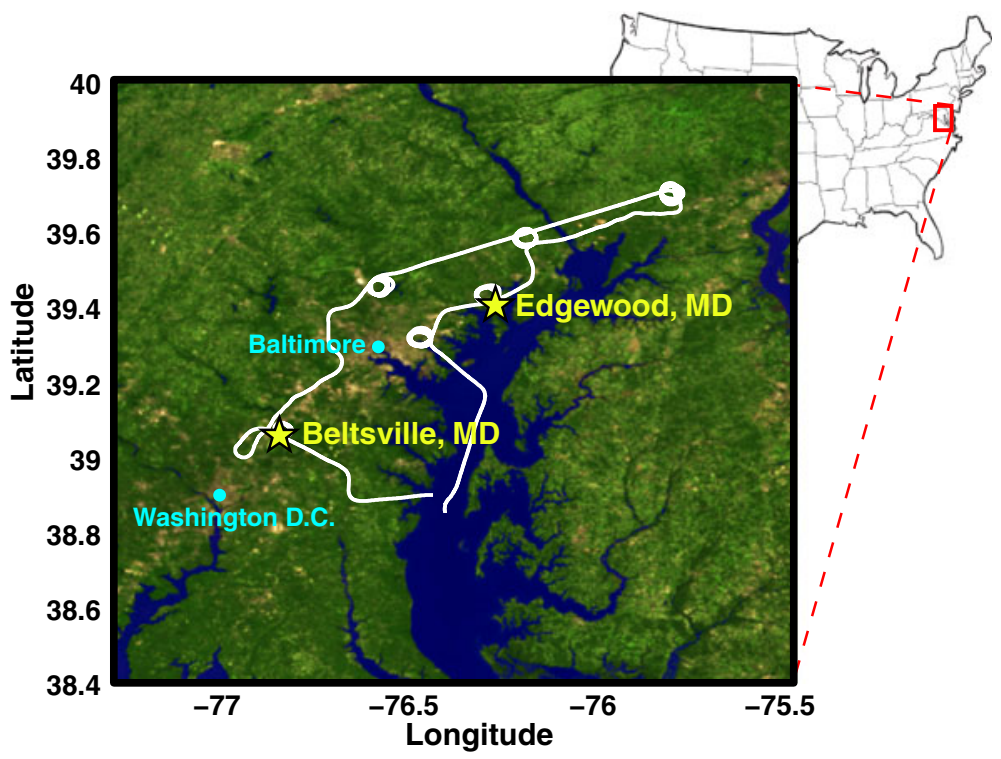

Fig. 1 Site map of the NASA DISCOVER-AQ July 2011 campaign in the Baltimore, MD/Washington D.C. metropolitan region. Ground measurement sites of interest are noted by the yellow stars. An example flight track of the NASA P3-B aircraft is indicated by the white line, with circles representing locations of vertical profiles 
Geostationary Coastal and Air Pollution Events, GEO-CAPE; National Research Council 2007; Europe, Sentinel-4; Committee on Earth Observation Satellites 2009; Ingmann et al. 2012; Asia, Korean Geostationary Environment Monitoring Spectrometer, GEMS and Geostationary Mission for Meteorology and Air Pollution, GMAP-Asia; Akimoto et al. 2008; TEMPO, http://science.nasa.gov/missions/tempo/).

\section{Measurements}

A total of 39 ozonesondes were launched at EW and 25 at BV during the campaign. The $\mathrm{O}_{3}$ instrument at EW comprised of an electrochemical concentration cell (ECC; Droplet Measurement Technologies, DMT) containing $1 \%$ solution by mass of potassium iodide (KI) in deionized water and fully-buffered $(0.625 \%$ sodium phosphate and $2.5 \%$ potassium bromide by mass; Komhyr 1986). The DMT sonde is manufactured to the same specifications as the ENSCI-2Z (Environmental Science Corporation) sondes flown in prior Maryland soundings (Thompson et al. 2007; Yorks et al. 2009). At BV, a DMT ozonesonde and a $0.5 \% \mathrm{KI}$, half-buffered solution was used. The nominal uncertainty of $\mathrm{O}_{3}$ measurements in the troposphere is $5 \%$ (e.g. Deshler et al. 2008), but the uncertainty is dependent on the electrochemical solution strength and ambient pressure. Data were collected at $1 \mathrm{~Hz}$ as the balloon ascends and the data were transmitted in real time to a ground station using an attached radiosonde (International Met Systems, iMet-1 at EW and Vaisala, RS-92 at BV). The radiosonde provides pressure, temperature, humidity, wind speed and direction, and georeference information. The pressure, temperature and humidity on the radiosonde are accurate to within $0.5 \mathrm{hPa}, 0.2{ }^{\circ} \mathrm{C}$ and $5 \%$, respectively. The almost daily ozonesonde launches coincided with aircraft vertical profiles (discussed below) during flight days and the approximate overpass of the Aura satellite ( 13:45 LT) on non-flight days. The mean height at apogee was $31.7 \mathrm{~km}$ with an average ascent time of $99 \mathrm{~min}$. Maximum distances of the balloon to the respective ground station ranged from 19 to $88 \mathrm{~km}$ with a median of $47 \mathrm{~km}$. The distance between the site and the balloon typically peaked at the top of the troposphere.

Ozonesonde data were validated against coincident aircraft profiles within the boundary layer and the lower free troposphere. The NASA P3-B, a four-turboprop engine aircraft, conducted 45 profiles over EW and 43 profiles over BV during the DISCOVER-AQ July 2011 campaign. The average minimum and maximum altitudes over which the aircraft flew over EW were $0.3 \mathrm{~km}$ and $3.6 \mathrm{~km}$, respectively. Profiles over BV were between $0.3 \mathrm{~km}$ and $1.7 \mathrm{~km}$. The aircraft profiling depth over BV was limited by airspace regulations. A typical spiral of the aircraft was $5 \mathrm{~km}$ in diameter and each profile took on average $14 \mathrm{~min}$. On the $\mathrm{P} 3-\mathrm{B}, \mathrm{O}_{3}$ is measured in-situ via the chemiluminescent reaction it undergoes with excess nitric oxide (NO; Ridley et al. 1992). A 2 standard cubic centimeters per minute (sccm) flow of pure NO is added to the $480 \mathrm{sccm}$ flow of ambient air, and the photons produced are counted using a photomultiplier tube cooled with dry ice. The approximate response time is $1 \mathrm{~s}$ and the data are reported at $1 \mathrm{~Hz}$. Over the course of the DISCOVER-AQ 2011 campaign, the instrument was calibrated on the ground three times against a Teco Model 49PS calibrator, and the calibration was stable to a nominal $3 \%$. Given this, and the intrinsic uncertainty in the calibrator, we estimate an overall uncertainty of $5 \%$ in the chemiluminescent measurement of $\mathrm{O}_{3}$. For the levels of $\mathrm{O}_{3}$ typical of the DISCOVER-AQ campaign, the precision in the $1-\mathrm{s}$ values is in the range $0.2-0.4 \mathrm{ppbv}$, increasing with mixing ratio.

Ozonesonde measurements of total column, partial column and mixing ratio profiles at EW were compared with nadir-viewing TES observations on board the Aura satellite (Beer et al. 
2001). The level 2 (version 5) $\mathrm{O}_{3}$ products, which consist of global survey and special observation swaths of $\mathrm{O}_{3}$ profiles and total and tropospheric $\mathrm{O}_{3}$ column amounts, were used for these analyses. A total of 11 global surveys were conducted during the campaign. Three special observations occurred within the region during the campaign, focusing on BV, EW and Fair Hill, MD (another DISCOVER-AQ ground site $~ 50 \mathrm{~km}$ northeast of EW, Lat: 39.7014; Lon: -75.8600). The swaths have a horizontal resolution at the surface of $5.3 \mathrm{~km} \times 8.4 \mathrm{~km}$. Ozone mixing ratios are retrieved for 88 pressure levels including the surface with retrievals approximately every $600-800 \mathrm{~m}$. The higher number of tropospheric retrievals from TES and higher sensitivity of the instrument to $\mathrm{O}_{3}$ within the troposphere compared to similar satellite products from OMI favors using TES data for these analyses. Pixels from TES that were within $150 \mathrm{~km}$ and $3 \mathrm{~h}$ of ozonesonde launch locations were defined as coincident and used for the comparison. These coincidence criteria are stricter than those of previous studies (e.g. Worden et al. 2007a). A total of 3 TES overpasses were defined as coincident and used in this analysis: one global survey and two special observations (stares) over EW and BV. These satellite overpasses were coincident with three ozonesondes launched at EW and two ozonesondes at BV. A total of 28 TES scans were analyzed since the special observations contained between 13 and 14 scans per overpass. The scans were filtered using the reported retrieval master quality flag in addition to the "Ccurve" flag, which represents cases of unrealistic retrievals. Three scans on each edge of the special observation overpasses were not included in the analysis (J. Worden, personal communication). The filters reduced the number of scans analyzed to 12. The average reported precision of the total and tropospheric column $\mathrm{O}_{3}$ amount from TES for the data used are $1.1 \%$ and $5.4 \%$, respectively, with biases in the tropospheric mid-latitudes between 10 and $20 \%$ (Nassar et al. 2008; Boxe et al. 2010) .

\section{Ozonesonde corrections}

Uncertainties in the $\mathrm{O}_{3}$ measurement from the sondes are a function of altitude typically ranging from 5 to $10 \%$, however, previous studies have shown a high bias when using the $1 \% \mathrm{KI}$, fully-buffered solution with ENSCI-2Z ECCs when compared to a UV photometer during controlled experiments (Barnes et al. 1985; Johnson et al. 2002; Smit et al. 2007; Deshler et al. 2008). Sensitivity tests of the $\mathrm{O}_{3}$ response show that the buffer concentration is the major contributing factor towards the high bias (Johnson et al. 2002), most likely due to side reactions involving hypoiodite and perphospate leading to an additional source of iodine (Saltzman and Gilbert 1959). Using a $1 \%$ solution strength at Edgewood, MD allowed the opportunity to conduct field observations with coincident in situ measurements to identify the magnitude of the previously identified artifacts. Thus, $\mathrm{O}_{3}$ partial pressure data that were collected during DISCOVER-AQ 2011 at Edgewood, MD were corrected for this high bias by applying a correction based on the controlled experiments conducted as part of the Jülich Ozone Sonde Intercomparison Experiment (JOSIE) 1998 simulation (Smit et al. 2007). The correction presented below is independent of the background corrections and pump flow corrections summarized in Johnson et al. (2002).

The correction was calculated as follows: First, the relative bias profiles observed during JOSIE-1998 were averaged into $5 \mathrm{~km}$ vertical bins. The smoothed data were spatially interpolated corresponding to the measured altitudes of each ozonesonde using a cubic spline. The interpolated relative biases were multiplied by each $\mathrm{O}_{3}$ partial pressure measurement and subtracted from the actual measurement. Finally, the corrected partial pressures of $\mathrm{O}_{3}$ were converted to a volume mixing ratio using the in situ temperature and pressure measurements. 
Differences between the coincident $\mathrm{O}_{3}$ measurements collected from ozonesondes and in situ measurements from the P3-B using EW and BV profiles were observed (Fig. 2). The corrected sonde and uncorrected sonde measurements from EW are both presented. The data are $100 \mathrm{~m}$ bin averages with uncertainties presented every $500 \mathrm{~m}$ for clarity. Uncertainties are calculated as $\pm 1 \sigma$ using bootstrap sampling of 10,000 points. The mean bias $(M B)$ and coefficient of variation of the root-mean-squared error $\left(R M S E_{c v}\right)$ averaged over the vertical range of coincident measurements of the uncorrected ozonesonde data from EW referenced to the aircraft measurements are $13.3 \%$ and $13.6 \%$, respectively. With the correction, the $M B$ and $R M S E_{c v}$ become $0.4 \%$ and $9.6 \%$, within the combined uncertainty $(\sim 11 \%)$ of the respective measurements. The BV site used $0.5 \% \mathrm{KI}$, half-buffered solutions. The $M B$ and $R M S E_{c v}$ for Beltsville ozonesonde profiles are $6.1 \%$ and $6.9 \%$, respectively, in agreement with previous controlled simulations using $0.5 \% \mathrm{KI}$, half-buffered solutions (Smit et al. 2007). Since the biases were less than the estimated combined uncertainty of the P3-B and sonde $\mathrm{O}_{3}$ measurements and since this correction is strictly to compensate for the previously observed artifacts associated with using a $1 \% \mathrm{KI}$ solution, the correction was not applied to the Beltsville sonde data. The response time of the ozonesondes are between 20 and $30 \mathrm{~s}$, whereas the response time of the P3-B chemiluminescence ozone instrument is on the order of $1 \mathrm{~s}$. Thus, a spatial lag between the ozonesonde and aircraft measurements based on the ascent rate of the balloon is expected. The spatial lag was calculated as the maximum of the un-scaled cross-covariance between the ozonesonde and aircraft measurements. Each ozonesonde flight was treated separately. The altitude of the ozonesonde measurement was adjusted downward using the mean ascent rate between the time of measurement $\left(\mathrm{t}_{\mathrm{m}}\right)$ and $t_{m}$ minus the lag time. When the lag of the ozonesonde measurements is taken into account and compared with the aircraft measurements, the $M B$ and $R M S E_{c v}$ is reduced to $0.1 \%$ and $8.3 \%$. Although the corrections increase the average uncertainty of $\mathrm{O}_{3}$ mixing ratios from ozonesondes throughout the entire ozonesonde profile from $8 \%$ to $9 \%$, these results show that this correction, based on independent controlled simulations, is sensible for these measurements. The bias correction was applied to all EW ozonesonde measurements hereafter and the response time correction was applied to both EW and BV sondes.

There is potential for this correction to be applied in the post-processing of past ozonesonde measurements using $\mathrm{ECC} \mathrm{O}_{3}$-detection methods and a $1 \% \mathrm{KI}$ solution, fully

Fig. 2 Comparison of percent error between the coincident ozonesondes and P3-B ozone profiles at Edgewood, MD (black) during July 2011 using uncorrected (dashed) and corrected (for chemical artifacts, solid) data. Uncorrected data from Beltsville, MD is shown (gray). The Beltsville profile comparisons do not exceed $2 \mathrm{~km}$ due to the airspace limitations placed on the P3-B aircraft. Profile data are $100 \mathrm{~m}$ bin-averages. The error bars (presented every $500 \mathrm{~m}$ for clarity) represent \pm 1 standard deviations calculated from bootstrap statistics

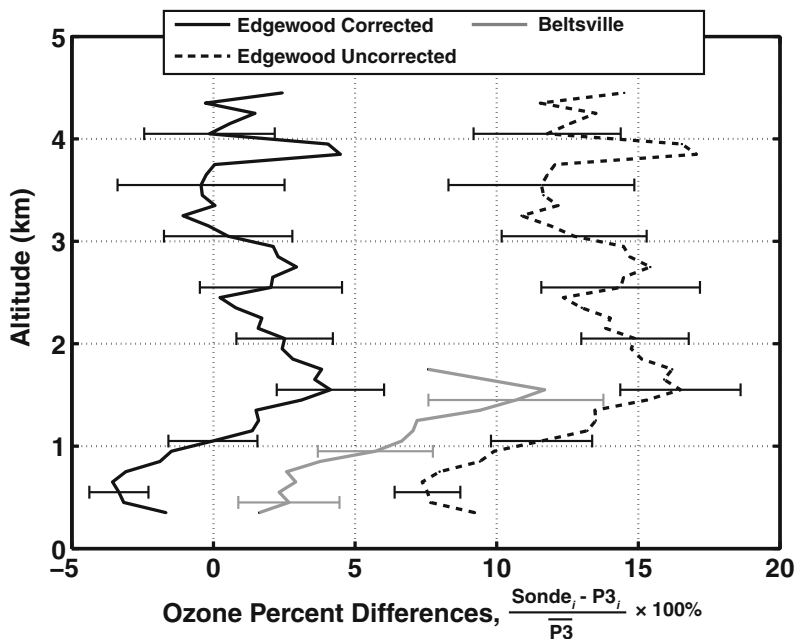


buffered. The challenges faced by long-term $\mathrm{O}_{3}$-monitoring networks such as the Global Atmospheric Watch (GAW), the Network for the Detection of Atmospheric Composition Change (NDACC) and the Southern Hemisphere Additional Ozonesondes (SHADOZ; e.g. Thompson et al. (2003) require a standardized approach to $\mathrm{O}_{3}$ measurement so that longterm trends can be accurately deduced (Smit et al. 2011). This correction provides the steps for one method of standardizing ECC-sonde types using the fully-buffered $1 \% \mathrm{KI}$ solution. It should be noted that the results of this correction are from one inter-comparison experiment extending only up to $5 \mathrm{~km}$ and further inter-comparisons, especially in the mid-toupper troposphere are needed to determine if these methods can generally be extended to other locations and altitudes. Although the corrections as described here are used for subsequent analyses in this manuscript, we note that other correction algorithms have been proposed (e.g. Deshler et al. 2012).

\section{Ozone profiles}

Ozone profile shapes are similar over EW and BW (Fig. 3). A local maximum of $\mathrm{O}_{3}$ mixing ratios in the mid-to-top of the boundary layer $(\sim 2 \mathrm{~km})$ is observed at both sites, presumably due to a combination of precursor availability, reaction time and surface loss processes. Above the boundary layer, $\mathrm{O}_{3}$ decreases due to the general lack of emission and transport of precursors into the lower free troposphere as inferred by steep gradients of species such as formaldehyde, carbon monoxide and nitrogen dioxide measured by the P3-B aircraft above both sites during the campaign (not shown). Ozone mixing ratios are relatively constant in the lower free troposphere up to $5 \mathrm{~km}$. Above $5 \mathrm{~km}$, the $\mathrm{O}_{3}$ mixing ratios increase with height, presumably due to vertical mixing between the troposphere and the high $\mathrm{O}_{3}$ concentrations of the stratosphere or contributions from $\mathrm{O}_{3}$ production chemistry stemming from upstream North American pollution.

TCO was calculated using $\mathrm{O}_{3}$ partial pressure measurements from ozonesondes and corrected for the amount between the burst altitude and the top of the atmosphere using a combination of Microwave Limb Sounder and ozonesonde climatological data (McPeters and Labow 2012). The observed mean TCO during the campaign was 337 DU with a day-today variability of $6 \%$. The TPCO, with the troposphere defined as the lowest altitude of a
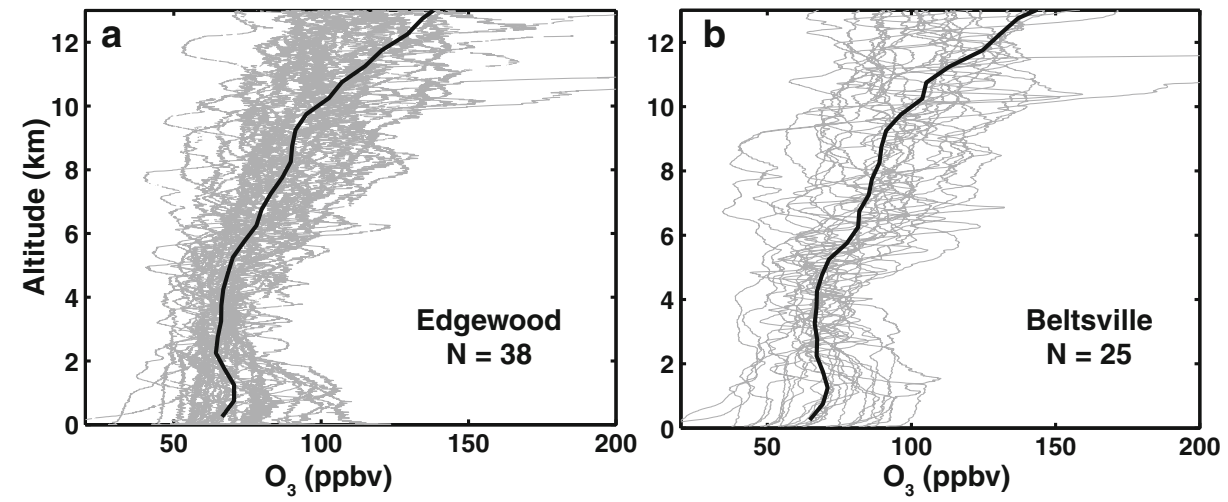

Fig. 3 Ozone mixing ratio vertical profiles from all ozonesondes ( $\mathrm{gray}$ ) launched during the DISCOVER-AQ July 2011 campaign over (a) Edgewood, MD and (b) Beltsville, MD. The mean vertical profile (black line) was calculated using $100 \mathrm{~m}$ bin averages 
$2 \mathrm{~km}$ thick layer having a lapse rate of $2 \mathrm{~K} \mathrm{~km}^{-1}$, on average composes $21 \%$ (69 DU) $\pm 3 \%$ $(1 \sigma)$ of the TCO and has a day-to-day variability of $21 \%$. The TPCO is significantly and positively correlated with TCO $(r=0.70, p$-val $<0.01)$. The variability of partial column $\mathrm{O}_{3}$ amounts within the 1-3 km, 4-6 km, and 7-10 km sub-regions are $27 \%, 23 \%$, and $32 \%$ $(2 \sigma)$ over EW and $36 \%, 26 \%$ and $38 \%$ over BV, respectively. As expected from the profile analysis, the variability is large within the boundary layer, decreases in the lower freetroposphere, and increases again in the mid-troposphere. Throughout the profile, the variability of the partial column $\mathrm{O}_{3}$ amounts is greater over $\mathrm{BV}$ compared to EW. The large variabilities in $\mathrm{O}_{3}$ partial columns during this one summer month, especially within the boundary layer, make forecasting this sub-region challenging, the implications of which are discussed below.

Five ozonesondes during the campaign coincided with three NASA Aura satellite overpasses. The TCO and TPCO measurements from the ozonesondes were compared to the same measurements retrieved from the TES (Table 1). For these analyses, the top of the troposphere was defined using the reported tropopause pressure from the Aura TES retrievals. The mean biases (ozonesondes as reference) of the TES TCO and TPCO are -3.2 DU $(-1.0 \%)$ and $0.2 \mathrm{DU}(0.4 \%)$, respectively. The coefficient of variations $\left(R M S E_{c v}\right)$ of the TES TCO and TPCO are $5.2 \%$ and $9.2 \%$, respectively. TES retrievals of TCO and TPCO over EW are generally lower than ozonesonde observations, while TES retrievals of TCO and TPCO over $\mathrm{BV}$ are higher than ozonesonde observations. This pattern over BV is also observed in comparisons of ozonesondes with TCO and trajectory-enhanced tropospheric ozone residual (TTOR) products from OMI. The results over EW contrast with previous validations of TES (Osterman et al. 2008; Nassar et al. 2008; Richards et al. 2008; Boxe et al. 2010), which find that TES column and profile retrievals, particularly in the troposphere, have a high bias between 0 and $20 \%$. These differences may be attributed, in part, to increased surface pollution at EW in July, to which satellite measurements are not sensitive and highlights the differences in observations between an intensive campaign such as DISCOVER-AQ and a more seasonal study. A comparison of TES $\mathrm{O}_{3}$ profile retrievals to coincident ozonesondes show that, qualitatively, the two types of measurements agree well (Fig. 4). The differences between the TES ozone profile retrievals to the a priori show that TES is responding to changes in radiances throughout most of the troposphere, although the responses vary vertically. The differences between the TES profile and the a priori profile are larger in the mid-

Table 1 Comparison of total and tropospheric column amounts of ozone over Edgewood and Beltsville, MD using ozonesonde and TES observations

\begin{tabular}{|c|c|c|c|c|c|c|}
\hline Date [UTC] & $\begin{array}{l}\text { Ozonesonde } \\
\text { Site }\end{array}$ & $\begin{array}{l}\text { TES Scan ID } \\
\text { [Scan Type] }\end{array}$ & $\begin{array}{l}\text { Ozonesonde } \\
\text { Total Column } \\
{[D U]}\end{array}$ & $\begin{array}{l}\text { TES Total } \\
\text { Column } \\
{[D U]}\end{array}$ & $\begin{array}{l}\text { Ozonesonde } \\
\text { Tropospheric } \\
\text { Column }[D U]\end{array}$ & $\begin{array}{l}\text { TES } \\
\text { Tropospheric } \\
\text { Column }[D U]\end{array}$ \\
\hline 2011-07-07 18:27 & Edgewood & $\begin{array}{l}13001 \text { global } \\
\text { survey }\end{array}$ & 366 & 343 & 75 & 68 \\
\hline 2011-07-14 18:33 & Edgewood & $\begin{array}{c}13019 \text { stare } \\
\text { Beltsville }\end{array}$ & 344 & 326 & 52 & 53 \\
\hline 2011-07-16 18:21 & Edgewood & $\begin{array}{c}13043 \text { stare } \\
\text { Edgewood }\end{array}$ & 341 & 331 & 65 & 61 \\
\hline 2011-07-14 18:33 & Beltsville & $\begin{array}{c}13019 \text { stare } \\
\text { Beltsville }\end{array}$ & 307 & 326 & 45 & 53 \\
\hline 2011-07-16 18:21 & Beltsville & $\begin{array}{l}13043 \text { stare } \\
\text { Edgewood }\end{array}$ & 316 & 331 & 57 & 61 \\
\hline
\end{tabular}


Fig. 4 Coincident TES (gray line) and ozonesonde $\mathrm{O}_{3}$ mixing ratio profiles over EW (black line) and $\mathrm{BV}$ (green line) during

DISCOVER-AQ in July 2011. The TES a priori $\mathrm{O}_{3}$ mixing ratio profile (black dashed) is shown for each overpass. The times (UTC) of the TES overpasses and the launch times of the ozonesondes are shown. Error bars on TES mixing ratio profiles represent $1 \sigma$ of multiple scans during the stare observations. There were no coincident ozonesonde launches over BV on July 7
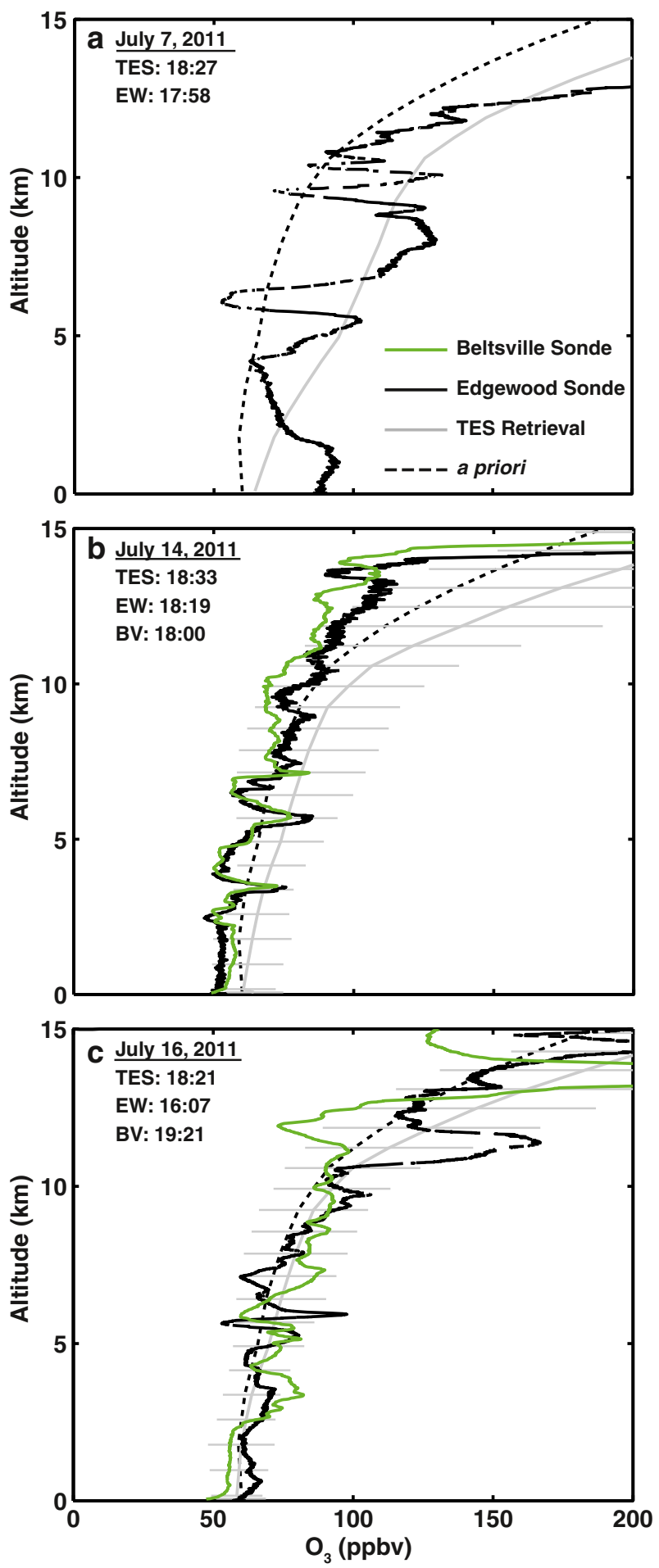
troposphere $(7-10 \mathrm{~km})$ compared to the boundary layer $(0-3 \mathrm{~km})$, which is expected based on the limited information the satellite receives from within the boundary layer. In the case of July 14, the a priori seems to do a better job than the TES profile retrieval when compared to the ozonesondes.

\section{Upper air-surface comparisons}

Using data from ozonesondes, correlations between upper air $\mathrm{O}_{3}$ and the near-surface $\mathrm{O}_{3}$ from EW and BV were calculated (Fig. 5). Data were averaged into $100 \mathrm{~m}$ vertical bins, the near-surface representing 0-100 m AGL and each layer was correlated with the near-surface. The correlation coefficient profiles show 3 laminae. Within the boundary layer (generically as $<3 \mathrm{~km}$ ), the correlation between layers aloft and the surface decreases approximately linearly with height at both EW and BV. The decrease of the correlation coefficient in the boundary layer at EW is greater than BV. In the free troposphere $(3-10 \mathrm{~km})$, the correlation coefficients are approximately constant with height, with an average correlation coefficient of $0.16 \pm 0.09(1 \sigma)$ over EW and $0.50 \pm 0.07(1 \sigma)$ over BV, the correlation over BV being significant at the $95 \%$ confidence level $(p$-val $=0.02)$. Above $10 \mathrm{~km}$, there is a decrease in the correlation coefficients and the coefficients become negative in the stratosphere. In the $\mathrm{BV}$ ozone correlation profile, $\mathrm{O}_{3}$ mixing ratios in layers aloft significantly ( $>95 \%$ confidence) correlate with the $\mathrm{O}_{3}$ mixing ratios within the near-surface layer up to $10 \mathrm{~km}$ (Fig. 5 bold lines). In contrast, $\mathrm{EW} \mathrm{O}_{3}$ mixing ratios in layers aloft significantly correlate with the $\mathrm{O}_{3}$ mixing ratios within the near-surface layer up to $3 \mathrm{~km}$.

The steeper gradients and the lower values of the correlation coefficients over EW reflect the dynamic complexity of the site due to its proximity to the Chesapeake Bay, in agreement with past observations (Loughner et al. 2011; Stauffer et al. 2013). To illustrate, boundary layer heights were calculated for each ozonesonde over EW and BV using a modified lapse rate method (Heffter 1980). Potential temperature profiles were smoothed by calculating $50 \mathrm{~m}$ vertical bin averages. The boundary layer height was defined as the lowest layer to

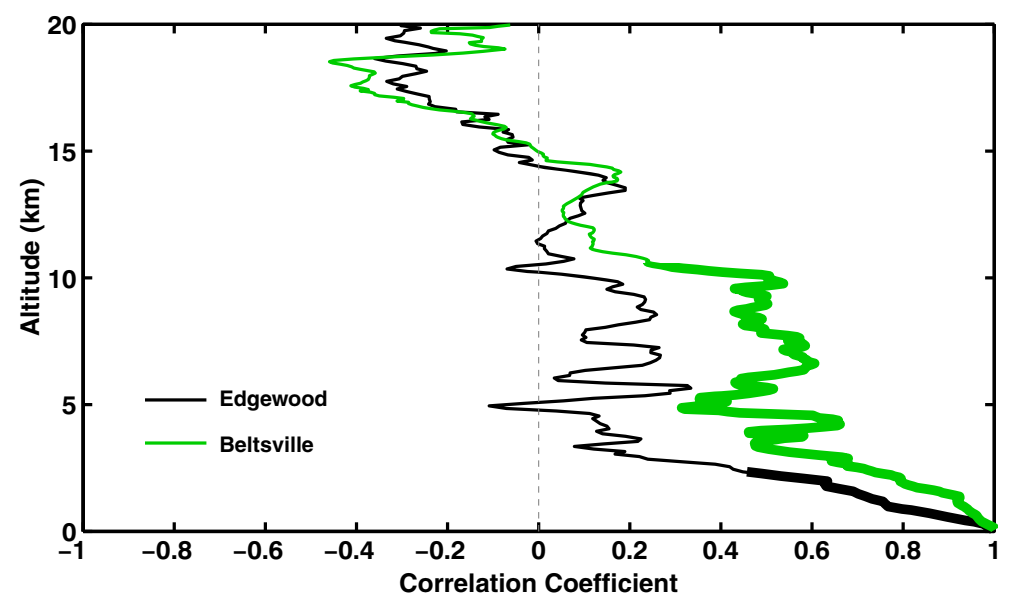

Fig. 5 Vertical profile of correlation coefficients between layers aloft and the surface $(0-100 \mathrm{~m})$ over Edgewood (black) and Beltsville (green). Thicker lines indicate areas where correlations are significant based on $95 \%$ confidence intervals $(p-v a l<0.05)$ 
exceed a lapse rate of $7 \mathrm{~K} \mathrm{~km}^{-1}$ and the layer must be above $200 \mathrm{~m}$. Ozonesondes that were launched during cloudy or rainy conditions, as determined by radiation measurements at each site and defined as having incoming total irradiance of less than $50 \%$ of the maximum observed daily mean irradiance, were excluded from the analysis. Based on this criterion, one BV ozonesonde and five EW ozonesondes were excluded for the boundary layer height analysis. Boundary layer heights calculated from ozonesonde data using this method compare somewhat well $(M B=-0.076 \mathrm{~km})$ with an independent method using a mini micropulse aerosol lidar (Fig. $6 a$ ). The boundary layer height is obtained from lidar measurements using a gradient technique, since aerosols often are trapped near the surface by the capping inversion layer (Davis et al. 2000; Brooks 2003). Figure $6 b$ shows the difference in boundary layer heights over EW and BL as a function of time-of-day. A 4th order polynomial was fit to each dataset between 7 and 17 EST. At both sites, the boundary layer height increases throughout the day, as expected. However, boundary layer heights over BV are often higher and the variability of the boundary layer heights in the afternoon is less compared to over EW. The lower boundary layer heights at EW are the result of thermal internal boundary layers (TIBLS) induced from marine flow (Stauffer et al. 2013). TIBLs act to decouple surface air pollutant concentrations from those aloft, leading generally to the differences in the correlation coefficent profiles between marine (EW) and terrestrial (BV) observation sites (Fig. 5).

Correlations between every $100 \mathrm{~m}$ layer were considered for EW and BV (Fig. 7). The boundary layer is more decoupled from the lower free troposphere over EW compared to $\mathrm{BV}$, as expected from TIBL influences over EW. The correlations show three distinct layers over both sites where adjacent laminae are coupled, shown by the high correlation coefficient "triangles" adjacent to the diagonal centerline. These high correlation coefficients in these sub-regions suggest vertical mixing between those layers. The layer correlations were expected within two of the sub-regions: the boundary layer $(0-3 \mathrm{~km})$ and the upper troposphere $(10-14 \mathrm{~km})$. These layers are frequently perturbed by convective mixing and tropopause folding, respectively. The correlations within the mid-troposphere $(7-10 \mathrm{~km})$ is more unexpected since vertical motions within this layer are relatively weaker and occur over larger spatial and temporal scales, and the variability of $\mathrm{O}_{3}$ in the mid-troposphere is small compared to the boundary layer. Without more detailed analyses of case studies
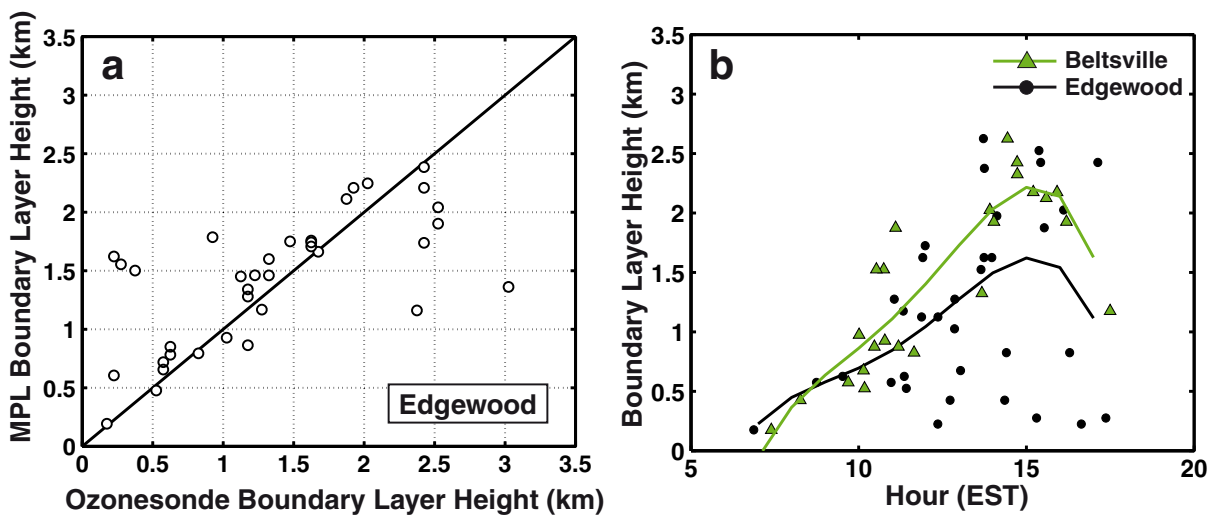

Fig. 6 (a) Comparison of independent methods of calculating the boundary layer height at Edgewood, MD presented with the 1:1 line and $(b)$ boundary layer height as a function of time of day over Beltsville, MD (green dots) and Edgewood, MD (black dots). A fourth-order polynomial was fit to the data over each site to show average diurnal patterns 

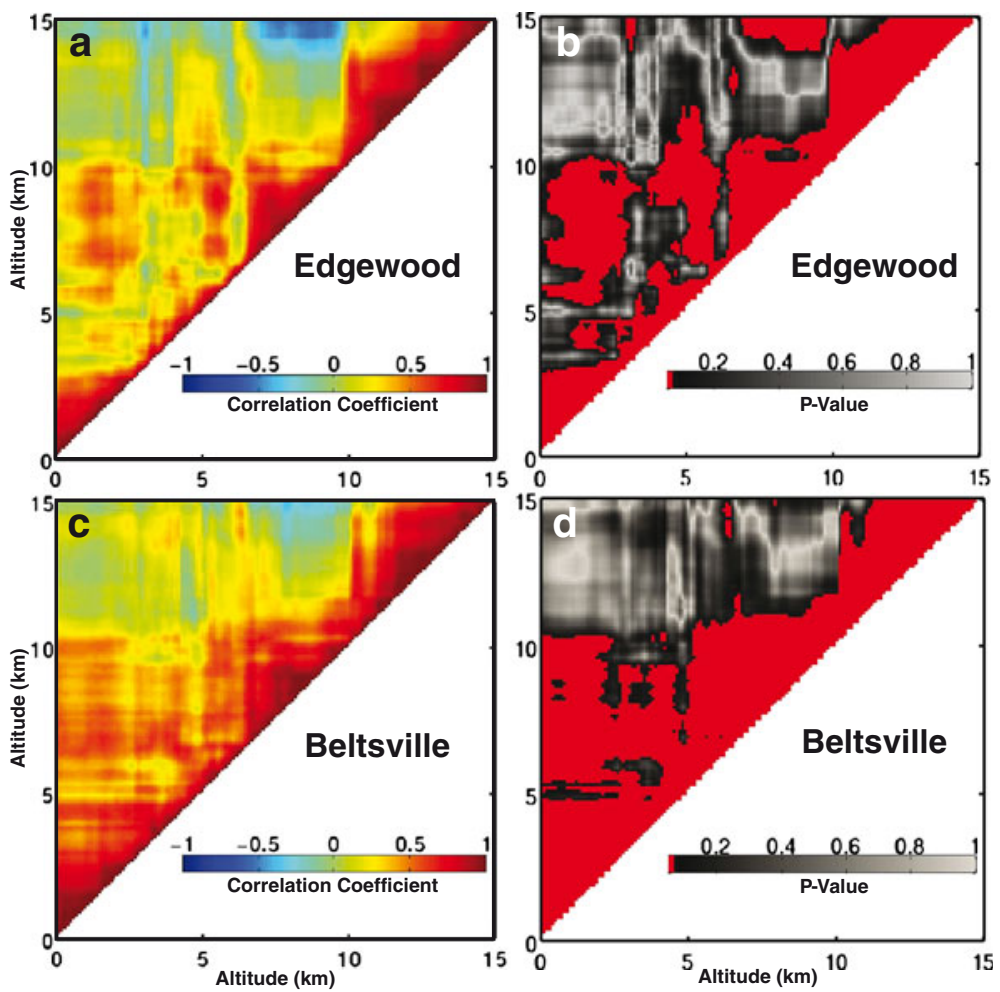

Fig. 7 (a,c) Correlation coefficients between $100 \mathrm{~m}$ layers as measured by ozonesondes over Edgewood and Beltsville, MD. $(b, d) P$-values of the correlations at the respective sites with the significant correlation coefficients $(\mathrm{pval}<0.05)$ shown in red

leading to the high correlations within $7-10 \mathrm{~km}$, we can only hypothesize based on previous work that these high correlations are due to either: 1) strong convection during extreme events, 2) large-scale vertical mixing associated with the passage of synoptic fronts or 3) long-range transport (Cooper et al. 2006, 2007; Gettelman et al. 2011).

The upper boundary layer $(1-3 \mathrm{~km}) \mathrm{O}_{3}$ mixing ratios show significant and positive correlations with the mid-troposphere $(7-10 \mathrm{~km}) \mathrm{O}_{3}$ mixing ratios over both sites, with average correlations of $0.42 \pm 0.09(1 \sigma)$ at $\mathrm{EW}$ and $0.43 \pm 0.09(1 \sigma)$ at BV within the subregion. Median p-values within the region are 0.01 (interquartile range $=0.00-0.03$ ) and 0.03 (interquartile range $=0.01-0.07$ ) at $\mathrm{EW}$ and $\mathrm{BV}$, respectively. An analysis of the $95 \%$ confidence intervals of the correlation coefficients calculated using a Fisher Transformation and associated $z$-statistical test show that most of the correlation coefficients between the mid-troposphere and near-surface are significant (Table 2). The significant correlations between the mid-troposphere and the near-surface are surprising especially at EW since the correlations between the near-surface and the lower free troposphere are not significant. However, this decoupling caused by TIBL influence show the complexity of the dynamics and the multiple dynamic and chemical processes occurring in the tropospheric column over a site. This discontinuity suggests that vertical transport is not a contributing factor for the correlations observed between the mid-troposphere and the near-surface. We speculate that synoptic phenomena such as available sunlight for photochemical processes coupled with the availability of precursors may be responsible for the significant correlations observed. 
Table 2 Confidence intervals of correlations observed at each site at specific quantiles between within the mid-tropospheric $(7-10 \mathrm{~km})$ and near-surface $(1-3 \mathrm{~km})$ vertical regions

\begin{tabular}{|c|c|c|c|c|c|c|}
\hline \multirow{3}{*}{ Percentile } & \multicolumn{3}{|l|}{ Edgewood } & \multicolumn{3}{|l|}{ Beltsville } \\
\hline & \multirow[t]{2}{*}{ Correlation } & \multicolumn{2}{|c|}{$95 \%$ Confidence Intervals } & \multirow[t]{2}{*}{ Correlation } & \multicolumn{2}{|c|}{$95 \%$ Confidence Interval } \\
\hline & & Upper & Lower & & Upper & Lower \\
\hline 90 & 0.54 & 0.73 & 0.28 & 0.54 & 0.77 & 0.18 \\
\hline 75 & 0.49 & 0.70 & 0.21 & 0.49 & 0.74 & 0.12 \\
\hline 50 & 0.41 & 0.65 & 0.11 & 0.44 & 0.71 & 0.05 \\
\hline 25 & 0.36 & 0.60 & 0.04 & 0.37 & 0.69 & -0.03 \\
\hline 10 & 0.31 & 0.57 & -0.01 & 0.30 & 0.62 & -0.11 \\
\hline
\end{tabular}

Given the location of these two sites downwind of major urban areas (Baltimore and Washington D.C.) and the fact that the mid-Atlantic region acts as an exhaust pipe for much of the contiguous United States, we speculate the occurrence of ozone precursors such as peroxyacetyl nitrate (PAN), carbon monoxide and volatile organic compounds (VOCs). These ideas are beyond the scope of this manuscript and are the subject of ongoing investigations. Further analyses below attempt to exploit this correlation by deriving near-surface $\mathrm{O}_{3}$ information using partial column $\mathrm{O}_{3}$ retrievals from satellites in the upper troposphere.

\section{Near-surface ozone prediction from partial column measurements}

Analogous to the $\mathrm{O}_{3}$ mixing ratio correlation analyses described above, the partial columns of $\mathrm{O}_{3}$ in the mid-troposphere (7-10 km; MTPC) and the near-surface partial columns of $\mathrm{O}_{3}$ (1-3 km; NSPC) were compared using ozonesonde measurements (Fig. 8). Correlation coefficients between these sub-regions were 0.56 and 0.49 for $\mathrm{EW}$ and $\mathrm{BV}$, respectively. Having considered the near-surface range between 1 and $3 \mathrm{~km}$ above the surface for both

Fig. 8 Scatter plots of near-surface (1-3 km) partial column ozone and upper troposphere (7-10 km) partial column ozone using ozonesondes over Edgewood, MD (black triangles) and Beltsville, MD (green dots). A least-squares regression line was fit to the data over each site

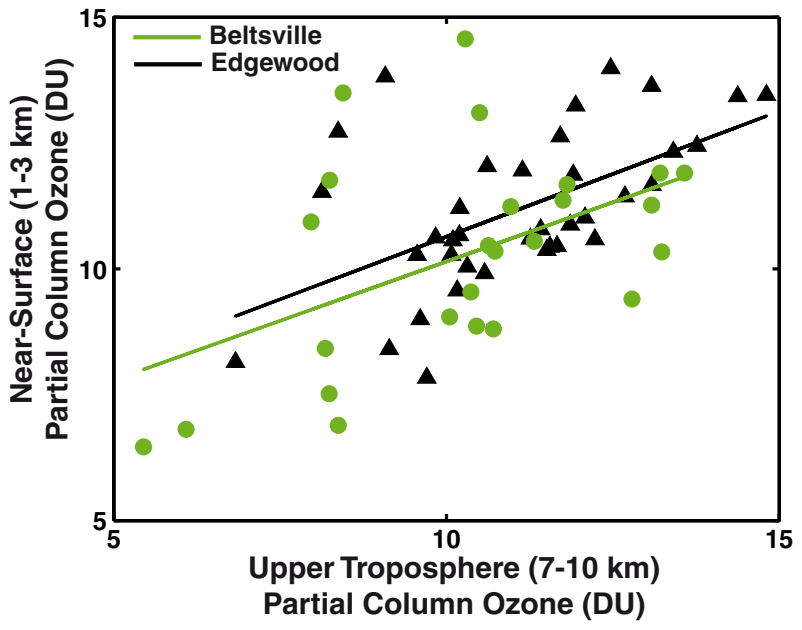


EW and BV rather than between 0 and $3 \mathrm{~km}$ above the surface increased the EW correlation coefficient by $17 \%$ with no change in the BV correlation coefficient. Thus, the impact of TIBLs at the EW site dramatically impacts partial column correlations. The linear regression statistics are similar at both sites (Table 3), giving confidence that these methods can be extended to other sites in the mid-Atlantic.

Further analyses were conducted to derive NSPC using MTPC as retrieved from TES using a regression model formulated from independent ozonesonde observations. The sensitivity and vertical resolution of TES is the largest in the 3-6 km layer as indicated by the averaging kernel profiles (Fig. 9). However, due to the dynamics at EW, no significant $\mathrm{O}_{3}$ correlations were observed between the near-surface and the 3-6 km layer, thus prediction of NSPC using satellite partial columns from 3 to $6 \mathrm{~km}$ was not considered for this study and mid-tropospheric $(7-10 \mathrm{~km})$ retrievals of TES were used. The averaging kernels binned into height layers also highlight the sensitivity limitations that satellites have within the boundary layer, further giving merit to the methods presented here. The NSPC derivations from TES were compared to coincident NSPC measurements from ozonesondes for validation. MTPCs (in Dobson units) were calculated from $\mathrm{TES}_{3}$ and pressure profile retrievals using:

$$
p c_{i}=\frac{\overline{N_{i} C_{i}} \Delta z}{2.69 \times 10^{20}}
$$

where $N_{i}$ is the number density in layer $i$ (in molecules $\mathrm{m}^{-3}$ ), $C_{i}$ is the mixing ratio in layer $i$ and $\Delta z$ is the height of layer $i$ (in $\mathrm{m}$ ). In this case, layer $i$ is defined between 7 and $10 \mathrm{~km}$. Prior to the calculation of the MTPCs, the TES $\mathrm{O}_{3}$ and pressure profiles were first linearly interpolated every $500 \mathrm{~m}$ and pressures at each height were calculated using the hypsometric equation from the nearest TES retrieved pressure level below. The $M B$ and $R M S E_{c v}$ of TES MTPC calculations referenced to ozonesonde measurements is $-8.4 \%$ and $9.9 \%$, respectively (Fig. 10). In general, TES partial columns in the mid troposphere underestimate the observations with a range between $-13 \%$ and $2 \%$. NSPCs derived from TES MTPC calculations using the linear regression coefficients presented in Table 3 for the respective sites differ from observed NSPCs from ozonesondes with a range of -1.3 to 0.9 DU (Fig. 10). The relative difference of the TES NSPCs ranges between -10 and $10 \%$, less than the observed variability in the nearsurface during the campaign. All the derived NSPC values from TES are within $11 \%$ of the ozonesonde observations. The $M B$ and $R M S E_{c v}$ for the TES NSPC comparisons to ozonesondes are $1.5 \%$ and $8.7 \%$, respectively. The uncertainty of the derived NSPC from satellites is less than the observed variability of partial column $\mathrm{O}_{3}$ amounts in that sub-region. These results show that by utilizing satellite information from the mid-troposphere, a region of the atmosphere in which satellites are more sensitive to changes in radiances and thus atmospheric composition, quantitative information can potentially be obtained with respect to atmospheric pollutants near the surface. The results obtained from this simple linear regression model and

Table 3 Regression statistics from linear regression of upper tropospheric $(7-10 \mathrm{~km})$ partial column ozone amounts on near-surface (1$3 \mathrm{~km}$ ) partial column ozone amounts using ozonesonde observations

\begin{tabular}{lll}
\hline Linear regression statistic & Edgewood & Beltsville \\
\hline Slope & 0.50 & 0.47 \\
Slope Error & 0.13 & 0.17 \\
y-Intercept $[D U]$ & 5.7 & 5.4 \\
Correlation Coef. & 0.56 & 0.49 \\
$p$-value & 0.01 & 0.03 \\
\hline
\end{tabular}


Fig. 9 TES averaging kernel profiles from select altitudes, color-coded by altitude bin, during the global survey overpass on 7 July 2011

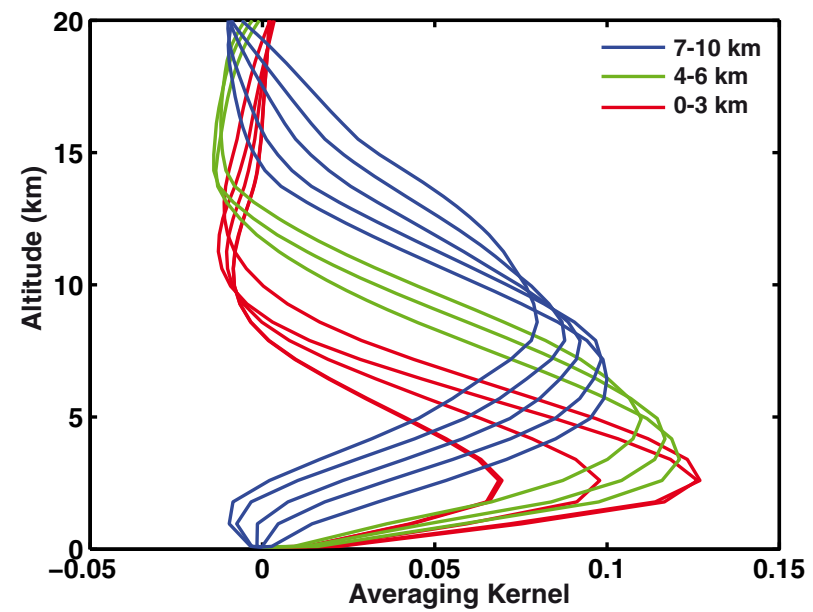

associated analyses are encouraging when considering the challenging task of retrieving nearsurface $\mathrm{O}_{3}$ information from satellites.

\section{Summary and conclusion}

NASA's DISCOVER-AQ campaign in the Baltimore, MD/Washington D.C. region in July 2011 provided a unique opportunity to inter-compare ozone profiling instrumentation as well as investigate correlations between upper tropospheric and near-surface $\mathrm{O}_{3}$ partial columns and concentrations. Comparisons between in situ aircraft $\mathrm{O}_{3}$ profiles and ozonesondes within the boundary layer and the lower free troposphere have confirmed systematic errors in the ozonesonde measurement previously observed in controlled simulations. These systematic errors were corrected using independent methods, reducing the mean bias between the ozonesondes and the in situ aircraft to less than $1 \%$.

Fig. 10 Comparison of measured $\mathrm{MTPC} \mathrm{O}_{3}$ from TES (blue squares) and ozonesondes (blue circles) during a total of 5 coincident TES overpass/ozonesonde launches. Additionally, the calculated NSPC from TES (red squares) and measured NSPC from ozonesondes (red circles) are compared. Error bars represent the propagated uncertainty caused by random errors

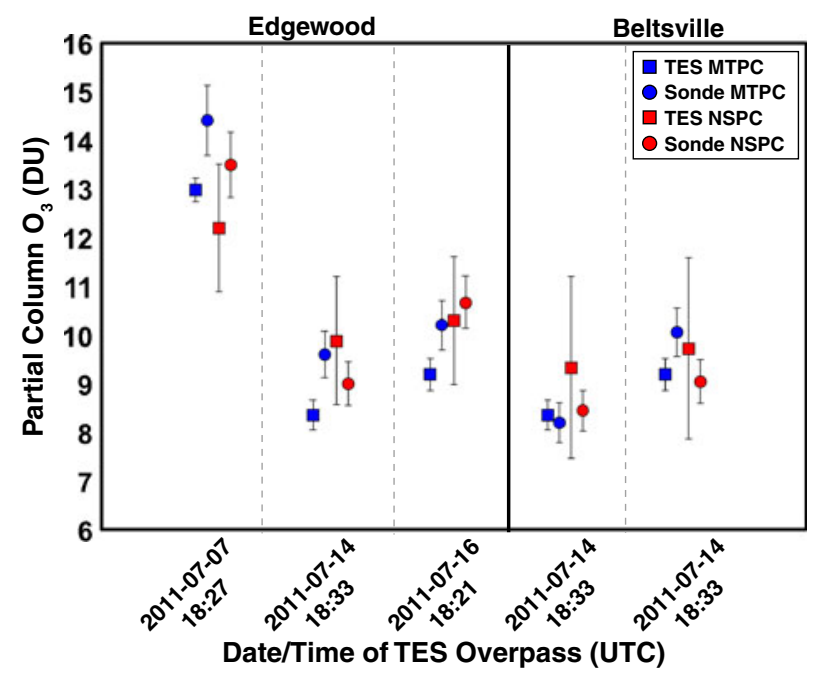

Springer 
Variability within $\mathrm{O}_{3}$ profiles is largest within the boundary layer and in the upper troposphere and the $\mathrm{O}_{3}$ profiles at two mid-Atlantic sites (Edgewood, MD and Beltsville, MD) are similar. The day-to-day variability of $\mathrm{O}_{3}$ within the total column is small (6\%), but is quite large $(21 \%)$ when only the tropospheric column, making up $\sim 21 \%$ of the total column, is considered. The variability of NSPCs from ozonesondes is large (27-36\%).

Upper air $\mathrm{O}_{3}$ concentrations are significantly positively correlated to surface $(0-100 \mathrm{~m})$ $\mathrm{O}_{3}$ up to $10 \mathrm{~km}$ at Beltsville, MD, but only up to $3 \mathrm{~km}$ at Edgewood, MD. The influences of marine layers at Edgewood, MD decouple the surface layer from those above, thus complicating retrieval algorithms over this site and presumably other coastal sites. However, significant positive correlations between upper troposphere $(7-10 \mathrm{~km})$ and near-surface (1-3 km) $\mathrm{O}_{3}$ exist over both sites, potentially providing solutions through regression analyses for retrieving near-surface $\mathrm{O}_{3}$.

The results presented in this manuscript were tested using current polar-orbiting $\mathrm{O}_{3}$ profile retrievals from NASA's TES instrument on board the Aura satellite, and validated against coincident ozonesonde profiles. Mid-troposphere partial columns calculated using ozonesonde and TES $\mathrm{O}_{3}$ profile measurements on average agree to within $20 \%$. Derived NSPCs, calculated from a linear regression model formulated from an independent ozonesonde dataset, agree with the ozonesonde observations within $11 \%$. Although the dataset used in these analyses are spatially and temporally limited, the results in this focused study show connections between the mid-troposphere and the near surface, which may not have otherwise been observed. These results are encouraging for obtaining near-surface $\mathrm{O}_{3}$ information using satellite measurements. The benefit of the techniques presented here is that they can be applied using existing satellite hardware and retrieval algorithms, as well as future geostationary satellite missions. The use of mid-tropospheric retrievals rather than retrievals from below $3 \mathrm{~km}$ has benefits: 1) TES is more sensitive within the midtroposphere compared to the boundary layer and 2) the retrievals are less likely to be impacted by clouds. The temporal resolution of the TES measurements at a particular ground site and the focused temporal range of this study limited the number of data samples in which to compare to ozonesondes. These analyses are limited in that they include data from only 64 ozonesondes at two Mid-Atlantic sites during one month in the summer. However, the intensive nature of these campaigns provides a thorough understanding of the atmospheric composition and the processes involved. Work to extend these analyses to other locations and other seasons using long-term ozonesonde observation data from Wallops Is., VA, Boulder, CO and more recently completed DISCOVER-AQ campaigns is in progress.

This research identifies the importance of the mid-tropospheric region $(7-10 \mathrm{~km})$ in terms of resolving the near-surface $\mathrm{O}_{3}$ partial column amounts. Research to develop algorithms that better quantify the $\mathrm{O}_{3}$ in the mid-troposphere, which utilize multiple wavebands and independent statistical correlations with atmospheric variables, is essential (Moody et al. 2012). The continuation of these studies will reduce satellite retrieval uncertainties in the troposphere and allow future geostationary satellite missions to be better utilized.

Acknowledgments This research was funded through the NASA DISCOVER-AQ project (\#NNX10AR39G) with additional support from the NASA sonde project (\#NNX08AJ15G). The authors would like to thank the NASA DISCOVER-AQ project leaders James Crawford (NASA Langley), Kenneth Pickering (NASA Goddard, University of Maryland), Mary Kleb (NASA Langley) and Gao Chen (NASA Langley) and all the DISCOVER-AQ investigators for their contributions. We thank the JOSIE-1998 investigators, especially Herman Smit (FZ-Juelich ICG-2), for providing data. The authors would like to thank Timothy Berkoff and Reuben Delgado for providing MPL data and analyses. Thank you to the Aura and TES science teams for providing satellite measurements and thank you to the Aura Validation Data Center Team at the NASA Goddard Space Flight Center for providing access to the data archive. For helpful edits and suggestions on the format and content of this work, we thank Jose Fuentes, 
Greg Garner, and Andra Reed (Pennsylvania State University). For logistical support, we thank Terry Meade, Mark Pippen and Matthew Nicodemus of the US Army Aberdeen Proving Ground.

Open Access This article is distributed under the terms of the Creative Commons Attribution License which permits any use, distribution, and reproduction in any medium, provided the original author(s) and the source are credited.

\section{References}

Akimoto, H., Kasai, Y., Kita, K.: Planning a Geostationary Atmospheric Observation Satellite. National Institute of Information and Communications Technology (2008)

Antón, M., López, M., Vilaplana, J.M., Kroon, M., McPeters, R., Bañón, M., Serrano, A.: Validation of OMITOMS and OMI-DOAS total ozone column using five Brewer spectroradiometers at the Iberian peninsula. J. Geophys. Res. 114, D14307 (2009). doi:10.1029/2009JD012003

Balis, D., Kroon, M., Koukouli, M.E., Brinksma, E.J., Labow, G., Veefkind, J.P., McPeters, R.D.: Validation of Ozone Monitoring Instrument total ozone column measurements using Brewer and Dobson spectrophotometer ground-based observations. J. Geophys. Res. 112, D24S46 (2007). doi: 10.1029/2007JD008796

Barnes, R.A., Bandy, A.R., Torres, A.L.: Electrochemical concentration cell ozonesonde accuracy and precision. J. Geophys. Res. 90(D5), 7881-7887 (1985)

Beer, R., Glavich, T.A., Rider, D.M.: Tropospheric emission spectrometer for the Earth Observing System's Aura satellite. Appl. Optics 40(15), 2356-2367 (2001)

Bowman, K., Worden, J., Steck, T., Worden, H.M., Clough, S., Rodgers, C.: Capturing time and vertical variability of tropospheric ozone: A study using TES nadir retrievals. J. Geophys. Res. 107, D23 (2002). doi:10.1029/2002JD002150

Bowman, K.W., Rodgers, C.D., Kulawik, S.S., Worden, J., Sarkissian, E., Osterman, G., Steck, T., Lou, M., Eldering, A., Shephard, M., Worden, H., Lampel, M., Clough, S., Brown, P., Rinsland, C., Gunson, M., Beer, R.: Tropospheric emission spectrometer: retrieval method and error analysis. IEEE Trans. Geosci. Remote Sens. 44(5), 1297-1307 (2006)

Boxe, C.S., Worden, J.R., Bowman, K.W., Kulawik, S.S., Neu, J.L., Ford, W.C., Osterman, G.B., Herman, R.L., Eldering, A., Tarasick, D.W., Thompson, A.M., Doughty, D.C., Hoffmann, M.R., Oltmans, S.J.: Validation of northern latitude Tropospheric Emission Spectrometer stare ozone profiles with ARC-IONS sondes during ARCTAS: sensitivity, bias and error analysis. Atmos. Chem. Phys. 10, 9901-9914 (2010)

Brooks, I.M.: Finding boundary layer top: application of a wavelet covariance transform to lidar backscatter profiles. J. Atmos. Ocean. Technol. 20, 1092-1105 (2003)

Chatfield, R.B., Esswein, R.F.: Estimation of surface $\mathrm{O}_{3}$ from lower-troposphere partial-column information: vertical correlations and covariances in ozonesonde profiles. Atmos. Environ. 61, 103-113 (2012)

Clerbaux, C., Boynard, A., Clarisse, L., George, M., Hadji-Lazaro, J., Herbin, H., Hurtmans, D., Pommier, M., Razavi, A., Turquety, S., Wespes, C., Coheur, P.-F.: Monitoring of atmospheric composition using the thermal infrared IASI/MetOp sounder. Atmos. Chem. Phys. 9, 6041-6054 (2009)

Committee on Earth Observation Satellites: Report on the Committee on Earth Observation Satellites Atmospheric Composition Constellation Workshop on Air Quality. http://ceos.org/images/ACC4Reportfinal.pdf (2009)

Cooper, O.R., et al.: Large upper tropospheric ozone enhancements above midlatitude North America during summer: In situ evidence from the IONS and MOZAIC ozone measurement network. J. Geophys. Res. 111, D24S05 (2006). doi:10.1029/2006JD007306

Cooper, O.R., et al.: Evidence for a recurring eastern North America upper tropospheric ozone maximum during summer. J. Geophys. Res. 112, D23304 (2007). doi:10.1029/2007JD008710

Davis, K.J., Gamage, N., Hagelberg, C.R., Kiemle, C., Lenschow, D.H., Sullivan, P.P.: An objective method for deriving atmospheric structure from airborne lidar observations. J. Atmos. Ocean. Technol. 17, 14551468 (2000)

Deshler, T., Mercer, J.L., Smit, H.G.J., Stubi, R., Levrat, G., Johnson, B.J., Oltmans, S.J., Kivi, R., Thompson, A.M., Witte, J., Davies, J., Schmidlin, F.J., Brothers, G., Sasaki, T.: Atmospheric comparison of electrochemical cell ozonesondes from different manufacturers, and with different cathode solution strengths: the Balloon Experiment on Standards for Ozonesondes. J. Geophys. Res. 113, D04307 (2008). doi:10.1029/2007JD008975

Deshler, T., Smit, H., Stübi, R., Kivi, R., Schmidlin, F.: Derivation of transfer functions to homogenize ozone measurements made with Science Pump and Ensci ozone sondes and using $1.0 \%$ or $0.5 \%$ KI solutions. http://larss.science.yorku.ca/QOS2012pdf/6177.pdf (2012) 
Fishman, J., Larsen, J.C.: Distribution of total ozone and stratospheric ozone in the tropics: implications for the distribution of tropospheric ozone. J. Geophys. Res. 92, 6627-6634 (1987)

Fishman, J., Creilson, J.K., Parker, P.A., Ainsworth, E.A., Vining, G.G., Szarka, J., Booker, F.L., Xu, X.: An investigation of widespread ozone damage to the soybean crop in the upper Midwest determined from ground-based and satellite measurements. Atmos. Environ. 44, 2248-2256 (2010)

Gettelman, A., Hoor, P., Pan, L.L., Randel, W.J., Hegglin, M.I., Birner, T.: The extratropical upper troposphere and lower stratosphere. Rev. Geophys. 49(RG303), 1-31 (2011). doi:10.1029/2011RG0000355

Goldberg, M.D., Qu, Y., McMillin, L.M., Wolf, W., Zhou, L., Divakarla, M.: AIRS near-real-time products and algorithms in support of operational numerical weather prediction. IEEE Trans. Geosci. Remote Sens. 41(2), 379-389 (2003)

Heffter, J.L.: Air resources Laboratories Atmospheric Transport and Dispersion Model. NOAA Tech. Memo. ERL ARL-81. NOAA Air Res. Lab, Silver Spring (1980). 24 pp

Ingmann, P., Veihelmann, B., Langden, J., Lamarre, D., Stark, H., Courrèges-Lacoste, G.B.: Requirements for the GMES Atmosphere Service and ESA's implementation concept: Sentinels-4/-5 and -5p. Remote. Sens. Environ. 120, 58-69 (2012)

Johnson, B.J., Oltmans, S.J., Vömel, H., Smit, H.G.J., Deshler, T., Kröger, C.: Electrochemical concentration cell (ECC) ozonesonde pump efficiency measurements and tests on the sensitivity to ozone of buffered and unbuffered ECC sensor cathode solutions. J. Geophys. Res. 107(D19), 4393 (2002). doi:10.1029/ 2001JD000557

Jourdain, L., Worden, H.M., Worden, J.R., Bowman, K., Li, Q., Eldering, A., Kulawik, S.S., Osterman, G., Boersma, K.F., Fisher, B., Rinsland, C.P., Beer, R., Gunson, M.: Tropospheric vertical distribution of tropical Atlantic ozone observed by TES during the northern African biomass burning season. Geophys. Res. Lett. 34, L04810 (2007). doi: 10.1029/2006GL028284

Kar, J., Fishman, J., Creilson, J.K., Richter, A., Ziemke, J., Chandra, S.: Are there urban signatures in the tropospheric ozone column products derived from satellite measurements? Atmos. Chem. Phys. 10, 5213-5222 (2010)

Komhyr, W.D.: Operations Handbook-Ozone Measurements to 40-km Altitude with Model 4A Electrochemical Concentration Cell (ECC) Ozonesondes (Used with 1680 MHz Radiosondes). NOAA Tech. Memo. ERL ARL-149. Air Res. Lab, Boulder (1986)

Kroon, M., Petropavlovskikh, I., Shetter, R., Hall, S., Ullmann, K., Veefkind, J.P., McPeters, R.D., Browell, E.V., Levelt, P.F.: OMI total ozone column validation with Aura-AVE CAFS observations. J. Geophys. Res. 113, D15S13 (2008). doi: 10.1029/2007JD008795

Kroon, M., de Haan, J.F., Veefkind, J.P., Froidevaux, L., Wang, R., Kivi, R., Hakkarainen, J.J.: Validation of operational ozone profiles from the Ozone Monitoring Instrument. J. Geophys. Res. 116, D18305 (2011). doi:10.1029/2010JD015100

Landgraf, J., Hasekamp, O.P.: Retrieval of tropospheric ozone: the synergistic use of thermal infrared emission and ultraviolet reflectivity measurements from space. J. Geophys. Res. 112, D08310 (2007). doi:10.1029/2006JD008097

Levelt, P.F., van den Oord, G., Dobber, M.R., Mälkki, A., Visser, H., de Vries, J., Stammes, P., Lundell, J.O.V., Saari, H.: The Ozone Monitoring Instrument. IEEE Trans. Geosci. Remote Sens. 44(5), 1093-1101 (2006)

Liu, X., Chance, K., Sioris, C.E., Kurosu, T.P., Spurr, R.J.D., Martin, R.V., Fu, T.-M., Logan, J.A., Jacob, D.J., Palmer, P.I., Newchurch, M.J., Megretskaia, I.A., Chatfield, R.B.: First directly retrieved global distribution of tropospheric column ozone from GOME: Comparison with the GEOS-CHEM model. J. Geophys. Res. 111, D10399 (2006). doi: 10.1029/2005JD006564

Liu, X., Bhartia, P.K., Chance, K., Spurr, R.J.D., Kurosu, T.P.: Ozone profile retrievals from the Ozone Monitoring Instrument. Atmos. Chem. Phys. 10, 2521-2537 (2010)

Loughner, C.P., Allen, D.J., Pickering, K.E., Zhang, D.-L., Shou, Y.-X., Dickerson, R.R.: Impact of fairweather cumulus clouds and the Chesapeake Bay breeze on pollutant transport and transformation. Atmos. Environ. 45, 4060-4072 (2011)

McPeters, R.D., Labow, G.J.: Climatology 2011: an MLS and sonde derived ozone climatology for satellite retrieval algorithms. J. Geophys. Res. 117, D10303 (2012). doi:10.1029/2011JD017006

Moody, J.L., Felker, S.R., Wimmers, A.J., Osterman, G., Bowman, K., Thompson, A.M., Tarasick, D.W.: A multi-sensor upper tropospheric ozone product (MUTOP) based on TES ozone and GEOS water vapor: Validation with ozonesondes. Atmos. Chem. Phys. 12, 5661-5676 (2012)

Nassar, R. et al.: Validation of Tropospheric Emission Spectrometer (TES) nadir ozone profiles using ozonesonde measurements. J. Geophys. Res. 113, D15S17 (2008). doi: 10.1029/2007JD008819

National Research Council: Earth science and applications from space: national imperatives for the next decade and beyond. National Academy Press, Wash. D.C (2007)

Natraj, V., Liu, X., Kulawik, S., Chance, K., Chatfield, R., Edwards, D.P., Eldering, A., Francis, G., Kurosu, T., Pickering, K., Spurr, R., Worden, H.: Multi-spectral sensitivity studies for the retrieval of tropospheric 
and lowermost tropospheric ozone from simulated clear-sky GEO-CAPE measurements. Atmos. Environ. 45, 7151-7165 (2011)

Osterman, G.B., Kulawik, S.S., Worden, H.M., Richards, N.A.D., Fisher, B.M., Eldering, A., Shephard, M.W., Froidevaux, L., Labow, G., Luo, M., Herman, R.L., Bowman, K.W., Thompson, A.M.: Validation of Tropospheric Emission Spectrometer (TES) measurements of the total, stratospheric, and tropospheric column abundance of ozone. J. Geophys. Res. 113, D15S16 (2008). doi:10.1029/2007JD008801

Richards, N.A.D., Osterman, G.B., Browell, E.V., Hair, J.W., Avery, M., Li, Q.: Validation of Tropospheric Emission Spectrometer ozone profiles with aircraft observations during the Intercontinental Chemical Transport Experiment-B. J. Geophys. Res. 113, D16S29 (2008). doi:10.1029/2007JD008815

Ridley, B.A., Grahek, F.E., Walega, J.G.: A small, high-sensitivity, medium-response ozone detector suitable for measurements from light aircraft. J. Atmos. Ocean. Technol. 9, 142-148 (1992)

Saltzman, B.E., Gilbert, N.: Iodometric microdetermination of organic oxidants and ozone: resolution of mixtures by kinetic colorimetry. Anal. Chem. 31(11), 1914-1920 (1959)

Schoeberl, M.R. et al.: A trajectory-based estimate of the tropospheric ozone column using the residual method. J. Geophys. Res. 112, D24S49 (2007). doi: 10.1029/2007JD008773

Sellitto, P., Bojkov, B.R., Liu, X., Chance, K., Del Frate, F.: Tropospheric ozone column retrieval at northern mid-latitudes from the Ozone Monitoring Instrument by means of a neural network algorithm. Atmos. Meas. Tech. 4, 2375-2388 (2011)

Smit, H.G.J., Straeter, W., Johnson, B.J., Oltmans, S.J., Davies, J., Tarasick, D.W., Hoegger, B., Stubi, R., Schmidlin, F.J., Northam, T., Thompson, A.M., Witte, J.C., Boyd, I., Posny, F.: Assessment of the performance of ECC-ozonesondes under quasi-flight conditions in the environmental simulation chamber: Insights from the Juelich Ozone Sonde Intercomparison Experiment (JOSIE). J. Geophys. Res. 112, D19306 (2007). doi:10.1029/2006JD007308

Smit, H.G.J. et al.: Quality Assurance and Quality Control for Ozonesonde Measurements in GAW. World Meteorological Organization, GAW Report No. 201 (2011)

Stauffer, R.M., Thompson, A.M., Martins, D.K., Clark, R.D., Goldberg, D.L., Loughner, C.P., Delgado, R., Dickerson, R.R., Stehr, J.W., Tzortziou, M.A.: Bay breeze influence on surface ozone at Edgewood, MD during July 2011. J. Atmos. Chem. (2013). doi: 10.1007/s10874-012-9241-6

Thompson, A.M., et al.: Southern Hemisphere Additional Ozonesondes (SHADOZ) 1998-2000 tropical ozone climatology: 1. Comparison with Total Ozone Mapping Spectrometer (TOMS) and ground-based measurements. J. Geophys. Res. 108(D2), 8238 (2003). doi:10.1029/2001JD000967

Thompson, A.M., et al.: Intercontinental Chemical Transport Experiment Ozonesonde Network Study (IONS) 2004: 1. Summertime upper troposphere/lower stratosphere ozone over northeastern North America. J. Geophys. Res. 112, D12S12 (2007). doi:10.1029/2006JD007441

Waters, J.W., et al.: The Earth Observing System Microwave Limb Sounder (EOS MLS) on the Aura satellite. IEEE Trans. Geosci. Remote Sens. 44(5), 1075-1092 (2006)

Worden, J., Kulawik, S.S., Shephard, M.W., Clough, S.A., Worden, H., Bowman, K., Goldman, A.: Predicted errors of tropospheric emission spectrometer nadir retrievals from spectral window selection. J. Geophys. Res. 109, D09308 (2004). doi: 10.1029/2004JD004522

Worden, H., Logan, J.A., Worden, J.R., Beer, R., Bowman, K., Clough, S.A., Eldering, A., Fisher, B.M., Gunson, M.R., Herman, R.L., Kulawik, S.S., Lampel, M.C., Luo, M., Megretskaia, I.A., Osterman, G.B., Shephard, M.W.: Comparisons of Tropospheric Emission Spectrometer (TES) ozone profiles to ozonesondes: Methods and initial results. J. Geophys. Res. 112, D03309 (2007). doi: 10.1029/ 2006JD007258

Worden, J., Liu, X., Bowman, K., Chance, K., Beer, R., Eldering, A., Gunson, M., Worden, H.: Improved tropospheric ozone profile retrievals using OMI and TES radiances. Geophys. Res. Lett. 34, L01809 (2007). doi: 10.1029/2006GL027806

Yorks, J.E., Thompson, A.M., Joseph, E., Miller, S.K.: The variability of free tropospheric ozone over Beltsville, Maryland $(39 \mathrm{~N}, 77 \mathrm{~W})$ in the summers 2004-2007. Atmos. Environ. 43, 1827-1838 (2009)

Ziemke, J.R., Chandra, S., Bhartia, P.K.: Two new methods for deriving tropospheric column ozone from TOMS measurements: Assimilated UARS MLS/HALOE and convective-cloud differential techniques. J. Geophys. Res. 103(D17), 22115-22127 (1998)

Ziemke, J.R., Chandra, S., Duncan, B.N., Froidevaux, L., Bhartia, P.K., Levelt, P.F., Waters, J.W.: Tropospheric ozone determined from Aura OMI and MLS: Evaluation of measurements and comparison with the Global Modeling Initiative's Chemical Transport Model. J. Geophys. Res. 111, D19303 (2006). doi:10.1029/ 2006JD007089

Zoogman, P., Jacob, D.J., Chance, K., Zhang, L., Le Sager, P., Fiore, A.M., Eldering, A., Liu, X., Natraj, V., Kulawik, S.S.: Ozone air quality measurement requirements for a geostationary satellite mission. Atmos. Environ. 45, 7143-7150 (2011) 